\title{
PRIMJENA DIGITALNOG MIKROSKOPA U UTVRĐIVANJU STUPNJA I DINAMIKE UČINKA HERBICIDA PENDIMETALINA NA RAST BAKTERIJA Bradyrhizobium japonicum
}

\author{
THE USE OF A DIGITAL MICROSCOPE IN THE EVALUATION OF \\ THE EFFECT OF HERBICIDE PENDIMETHALIN ON THE \\ GROWTH OF BACTERIA Bradyrhizobium japonicum
}

Filipa Burul, Ana Pintar, Klara Barić

\section{SAŽETAK}

Cilj istraživanja bio je primjenom digitalnog mikroskopa utvrditi utjecaj i dinamiku učinka različitih koncentracija herbicida pendimetalina na rast bakterije Bradyrhizobium japonicum. Istraživane koncentracije pendimetalina iznosile su 0,$00 ; 0,165 ; 0,33 ; 0,66 ; 1,32$ i $2,64 \%$. Koncentracija $0,66 \%$ odgovara količini pendimetalina koja se uobičajeno primjenjuje u praksi (registrirana dozacija). Utjecaj pendimetalina na rast bakterija utvrđivan je mjerenjem širine zone inhibicije oko filter-diskova tretiranih istraživanim koncentracijama pendimetalina 5, 7, 10 i 12 dana nakon nacjepljivanja (DNN) bakterija na hranjivu podlogu. Najmanji inhibitorni učinak utvrđen je kod prvog mjerenja (5 DNN), kad se prosječna širina zone inhibicije kretala od $0,18 \mathrm{~mm}$ kod najniže $(0,165 \%)$ do $0,97 \mathrm{~mm}$ kod najviše $(2,64 \%)$ istraživane koncentracije. Pri svakom sljedećem mjerenju utvrđena je progresija inhibitornog učinka pendimetalina na rast bakterija. Najveći inhibitorni učinak utvrđen je kod posljednjeg mjerenja (12 DNN) kad je širina zone inhibicije kod koncentracije pendimetalina od $0,165 \%$ iznosila $0,61 \mathrm{~mm}$. Povećanjem koncentracije znatno se povećavala, te je kod koncentracije od 2,64\% iznosila $2,46 \mathrm{~mm}$. Rezultati istraživanja ukazuju na negativan učinak herbicida pendimetalina na rast bakterija $B$. japonicum čak i kod koncentracija manjih od preporučene koja se primjenjuje u praksi.

Ključne riječi: Bradyrhizobium japonicum, digitalni mikroskop, inhibicija, pendimetalin 
Filipa Burul i sur.: Primjena digitalnog mikroskopa u utvrđivanju stupnja i dinamike učinka herbicida pendimetalina na rast bakterija Bradyrhizobium japonicum

\begin{abstract}
The objective of this study was to determine the effect of different concentrations of herbicide pendimethalin on the growth of nitrogen-fixing bacteria Bradyrhizobium japonicum using a digital microscope. Pendimethalin was applied at concentrations of $0.00 ; 0.165 ; 0.33 ; 0.66 ; 1.32$ and $2.64 \%$, where the concentration of $0.66 \%$ presents the amount of herbicide which is usually applied in the field (recommended dose). The influence of pendimethalin on the growth of $B$. japonicum was determined by measuring the width of the inhibition zone around the discs 5, 7, 10 and 12 days after inoculation (DAI) of bacteria on a nutrient medium. The lowest inhibitory effect of pendimethalin for all concentrations determined was 5 DAI, when the average width of inhibition zone was between $0.18 \mathrm{~mm}$ for the lowest $(0.165 \%)$ to $0.97 \mathrm{~mm}$ for the highest $(2.64 \%)$ concentration. The progression of the inhibitory effect of pendimethalin occurred with every following assessment. The highest inhibitory effect determined was 12 DAI, when the width of the inhibiton zone at a concentration of $0.165 \%$ was $0.61 \mathrm{~mm}$. The width of the inhibition zone significantly increased with increasing the pendimethalin concentrations and at a concentration of $2.64 \%$ it was $2.46 \mathrm{~mm}$. The results of this study indicate the negative effect of herbicide pendimethalin on bacteria B. japonicum, even at concentrations lower than recommended concentrations that are applied in the field.
\end{abstract}

Key words: Bradyrhizobium japonicum, digital microscope, inhibition, pendimethalin

\title{
UVOD I CILJEVI ISTRAŽIVANJA
}

Simbiotska fiksacija atmosferskog dušika najznačajniji je oblik simbiotskog odnosa između viših biljaka i mikroorganizama tla. Čak $90 \%$ biološki fiksiranog dušika potječe iz simbiotskog odnosa između kvržičnih bakterija iz rodova Rhizobium, Bradyrhizobium, Sinorhizobium, Azorhizobium i Mesorhizobium i većine biljaka iz porodice Leguminosae, što ga čini jednim od najvažnijih prirodnih procesa u poljoprivrednoj proizvodnji (Dreovn, 1983.; Topol i Kanižai Šarić, 2013.), a koji se sve više primjenjuje putem predsjetvene bakterizacije sjemena leguminoza (Sikora i sur., 2008.). Leguminoze kroz produkte fotosinteze opskrbljuju bakterije ugljikom odnosno energijom, a za uzvrat bakterije opskrbljuju leguminoze dušikom u obliku amonijaka kojeg biljke iskorištavaju za svoje potrebe (Blažinkov i sur., 2014.). Naime, učinkovito odvijanje simbiotske fiksacije dušika može značajno smanjiti 
Filipa Burul i sur.: Primjena digitalnog mikroskopa u utvrđivanju stupnja i dinamike učinka herbicida pendimetalina na rast bakterija Bradyrhizobium japonicum

potrebu primjene mineralnih dušičnih gnojiva u usjevu (Topol i Kanižai Šarić, 2013.) te, kako navodi Zahran (1999.), utjecati na povećanje prinosa usjeva uzgajanih nakon leguminoza. Prema autorima, prinos je često jednak onome koji se očekuje nakon primjene $30-80 \mathrm{~kg} \mathrm{ha}^{-1}$ mineralnog dušičnog gnojiva. Osim opskrbe biljke dušikom, biološkom fiksacijom dušika udovoljava se i zahtjevima pravilnog gospodarenja tlom, poput povećanja produktivnosti, ekonomičnosti i zaštite prirodnih resursa (Redžepović i sur., 2007.).

Fiksatori atmosferskog dušika, kao i cjelokupna bakterijska populacija u rizosferi, pod utjecajem su raznih abiotičkih i biotičkih faktora koji su u kompleksnoj interakciji. U nekim slučajevima spomenute interakcije mogu negativno utjecati na kvržične bakterije što rezultira smanjenjem njihove efikasnosti, a u nekim slučajevima i onemogućavanjem uspostave simbiotskog odnosa. Tako Zahran (1999.) navodi da je aplikacija pesticida jedan od najvažnijih i potencijalno limitirajućih faktora koji utječu na simbiotsku fiksaciju te da herbicidi, kao najčešće korišteni pesticidi, predstavljaju najveću opasnost za uspostavu i uspješno odvijanje simbiotskog odnosa između kvržične bakterije i biljke domaćina. Negativan utjecaj herbicida na kvržične bakterije očituje se kroz promjene u njihovoj bioraznolikosti, brojnosti, aktivnosti i ritmu razmnožavanja, kao i u izmjeni signala između bakterija i biljke domaćina, formiranju kvržica i aktivnosti nitrogenaze (Johnsen i sur., 2001.). Zbog toga je poznavanje utjecaja herbicida na simbiotsku fiksaciju dušika od iznimne važnosti, da bi se, u slučaju njihovog negativnog djelovanja, prepoznala potreba za primjenom herbicida na način koji predstavlja najmanju prijetnju za simbiotske fiksatore dušika. Međutim, kod velikog broja istraživanja u ovom području vrlo često se mogu uočiti neslaganja između različitih autora. Više autora navodi da je razlog tome nedostatak standardizirane metode istraživanja, odnosno neujednačen način ocjene učinka. Pokusi se postavljaju u laboratorijskim uvjetima, zaštićenim prostorima i u polju, a provedba i parametri mjerenja učinka znatno se razlikuju.

$\mathrm{Na}$ prvi pogled se provođenje pokusa u poljskim uvjetima čini najvjerodostojnijim. No, takva istraživanja su često kompleksna zbog utjecaja većeg broja vanjskih čimbenika na ponašanje herbicida u tlu i na simbiotske fiksatore dušika. Kao glavne čimbenike Ostojić (1989.) navodi fizikalnokemijska svojstva herbicida, dozu i vrijeme primjene, fizikalno-kemijska i biološka svojstva tla, vremenske prilike i agrotehničke mjere. Interakcija tih čimbenika u poljskim uvjetima predstavlja problem u kvantifikaciji utjecaja herbicida na istraživane mikroorganizme. 
Filipa Burul i sur.: Primjena digitalnog mikroskopa u utvrđivanju stupnja i dinamike učinka herbicida pendimetalina na rast bakterija Bradyrhizobium japonicum

Gonzales i sur. (1999.) navode da metribuzin primijenjen $u$ dozi od $0,48 \mathrm{~kg} \mathrm{ha}^{-1}$ na tlu $\mathrm{s}$ visokim sadržajem organske tvari $(5,7 \%)$ nije imao negativan učinak na nodulaciju bakterijom Bradyrhizobium japonicum. Suprotno navedenom, u pjeskovitom tlu, metribuzin je već pri dozi od $0,3 \mathrm{~kg} \mathrm{ha}^{-1}$ imao negativno djelovanje (Bollich i sur., 1985.). Naime, u pjeskovitom tlu je zbog slabijeg adsorpcijskog potencijala vezanja herbicida na čestice tla, veći dio primijenjenog herbicida došao u kontakt $\mathrm{s}$ bakterijom. U istraživanju Chebotar iz 1979. (cit. Rosolem i sur., 1985.) utvrđeno je da herbicid trifluralin, koji pripada istoj kemijskoj skupini (dinitroanilini) kao i u ovom radu istraživani pendimetalin, u dozama od $0,8,2,0$ i $30 \mathrm{~kg} \mathrm{ha}^{-1}$ ometa nodulaciju soje od strane bakterije $B$. japonicum. Utvrđena je redukcija nodulacije u rasponu od $22-58 \%$, kao i smanjena aktivnost nitrogenaze. Međutim, opisano inhibitorno djelovanje bilo je kratkotrajno te je utvrđena ponovna uspostava simbiotskog odnosa. Bollich (1985.) je u istraživanju s istim herbicidom utvrdio da doza od 1,80 $\mathrm{kg} \mathrm{ha}^{-1}$ izaziva promjene na tkivu korijena zbog čega nije ni došlo do nodulacije. Isti autor ističe da su primjenom različitih metoda istraživanja učinci herbicida na bakteriju B. japonicum bili različiti. Primjenom filter-disk metode kod svih istraživanih količina (10 i $1000 \mathrm{mg} \mathrm{l}^{-1}$ ) herbicida pendimetalina utvrđen je indiferentan učinak na bakteriju $B$. japonicum, dok je metodom inkorporacije herbicida u hranjivu podlogu utvrđen inhibitorni učinak. Suprotno navedenom, Naimarević (2014.) je primjenom iste metode (inkorporacija $\mathrm{u}$ hranjivu podlogu) $\mathrm{i}$ korištenjem jednakih količina herbicida utvrdio stimulativan učinak pendimetalina na rast bakterije. Blažinkov i sur. (2014.) su primjenom filter-disk metode utvrdili da pendimetalin primijenjen u količini od $10000 \mathrm{mg} \mathrm{l}^{-1}$ na pojedine sojeve vrste Rhizobium leguminosarum sv. viciae ima indiferentan, dok na ostale sojeve stimulativan učinak. $U$ istom istraživanju, herbicid imazamoks primijenjen $u$ istoj količini $\left(10000 \mathrm{mg} \mathrm{l}^{-1}\right)$ na sve istraživane sojeve imao je stimulativan učinak. Takav učinak imazamoksa primijenjenog u količinama od 10; 100; 1000 i $10000 \mathrm{mg} \mathrm{l}^{-1}$ utvrđen je i kod svih istraživanih sojeva vrste Sinorhizobium meliloti (Blažinkov i sur., 2010.). Herbicid klomazon primijenjen u količini od $1000 \mathrm{mg}^{-1}$ usporio je, a u nekim slučajevima $\mathrm{i}$ onemogućio rast istraživanih sojeva vrste Rhizobium leguminosarum sv. viciae (Blažinkov i sur., 2014.). Takvo djelovanje na vrstu Sinorhizobium meliloti utvrđeno je nakon primjene herbicida tifensulfuron-metila i fomesafena (Blažinkov i sur., 2010.).

Osim razlika u rezultatima, ovisno o metodologiji istraživanja, istraživanoj vrsti i soju bakterije, treba istaknuti i razlike u metodama utvrđivanja utjecaja 
Filipa Burul i sur.: Primjena digitalnog mikroskopa u utvrđivanju stupnja i dinamike učinka herbicida pendimetalina na rast bakterija Bradyrhizobium japonicum

herbicida na rast i razvoj bakterija fiksatora atmosferskog dušika. Naime, ranija istraživanja uglavnom su se zasnivala na subjektivnoj vizualnoj procjeni, dok je danas, zahvaljujući tehnološkim informatičkim dostignućima, moguće preciznije, a time i objektivnije utvrditi utjecaj herbicida (i drugih ksenobiotika) na simbiotski odnos bakterija i biljke domaćina.

Cilj ovog istraživanja bio je primjenom digitalnog mikroskopa utvrditi utjecaj i dinamiku učinka različitih koncentracija herbicida pendimetalina na rast bakterije $B$. japonicum te dobivene rezultate usporediti s rezultatima drugih autora koji su se u utvrđivanju učinka koristili vizualnim (subjektivnim) metodama procjene.

\section{METODE I MATERIJALI ISTRAŽIVANJA}

Za istraživanje učinka različitih koncentracija pendimetalina odabrana je filter-disk metoda (Heatley, 1944.) kojom se u bakteriologiji uobičajeno ispituje osjetljivost bakterija na ksenobiotike. Metoda podrazumijeva aplikaciju istraživanog herbicidnog pripravka $u$ različitim koncentracijama na diskove promjera $7 \mathrm{~mm}$ koji su postavljeni na površinu hranjive podloge na koju je prethodno bila nacijepljena čista bakterijska kultura vrste B. japonicum. Koncentracije pendimetalina korištene u istraživanju iznosile su 0,$00 ; 0,165$; 0,$33 ; 0,66 ; 1,32$ i $2,64 \%$, pri čemu koncentracija od $0,66 \%$ odgovora količini od 41 herbicidnog pripravka u 2001 vode koja se primjenjuje u praksi po hektaru. Svaka koncentracija pripravka, uključujući i kontrolnu varijantu (koncentracija 0) je postavljena u četiri ponavljanja. Nakon pipetiranja bakterijska kultura je raspoređena po podlozi pomoću L-štapića u količini od 1 $\mathrm{ml}$ po Petrijevoj zdjelici. Na nacijepljene podloge postavljena su četiri filterdisk papira $\mathrm{s}$ istraživanim koncentracijama herbicida. Diskovi su prethodno bili uronjeni u svako razrjeđenje (istraživanu koncentraciju) u trajanju od 30 minuta. $\mathrm{Na}$ hranjive podloge koje su predstavljale kontrolnu varijantu diskovi su u istom trajanju prethodno natopljeni destiliranom vodom. Razvoj bakterijske kulture odvijao se u klima komori pri kontroliranim uvjetima temperature $\left(25{ }^{\circ} \mathrm{C}\right)$ i vlage (61\%) zraka. Nakon razdoblja inkubacije u klima komori 5, 7, 10 i 12 dana nakon nacjepljivanja (DNN) obavljeno je mjerenje širine zone inhibicije rasta bakterije. Mjerenje je obavljeno Dino-Lite USB digitalnim mikroskopom $\mathrm{s}$ povećanjima od $40 \mathrm{x}$ i $50 \mathrm{x}$. Zone inhibicije rasta bakterije automatski su fotografirane pomoću istog softvera DinoCapture 2.0., koji omogućuje precizno mjerenje širine zone inhibicije od ruba diska do područja gdje se odvija normalan rast bakterije. 
Filipa Burul i sur.: Primjena digitalnog mikroskopa u utvrđivanju stupnja i dinamike učinka herbicida pendimetalina na rast bakterija Bradyrhizobium japonicum

Dobiveni podaci obrađeni su odgovarajućom analizom varijance $u$ programu SAS (1997). Nakon signifikantnog $F$-testa $(\mathrm{P}=0,05)$ za usporedbu srednjih vrijednosti korišten je LSD test $(\mathrm{P}=0,05)$.

\section{REZULTATI ISTRAŽIVANJA I RASPRAVA}

Za razliku od većine dostupnih rezultata istraživanja koji se temelje na subjektivnoj ocjeni učinka utjecaja herbicida na rast bakterija fiksatora atmosferskog dušika, u rezultatima ovog istraživanja pomoću softvera DinoCapture 2.0. prikazane su objektivne vrijednosti inhibicije istraživanog herbicida. Naime, kod subjektivne ocjene često zbog malih, odnosno, oku nevidljivih promjena, inhibicije nisu registrirane. Rezultati inhibitornog učinka pendimetalina na bakteriju $B$. japonicum ovisno o istraživanoj koncentraciji i broju dana nakon nacjepljivanja na hranjivu podlogu prikazani su u tablici 1.

Tablica 1. Širina zone inhibicije bakterije $B$. japonicum ovisno o koncentraciji pendimetalina i broju dana nakon nacjepljivanja (DNN)

Table 1 The widths of $B$. japonicum inhibition zones depending on the concentrations of pendimethalin and days after inoculation (DAI)

\begin{tabular}{|c|c|c|c|c|}
\hline & \multicolumn{4}{|c|}{$\begin{array}{c}\text { Šrina inhibicijske zone (mm)/ } \\
\text { The width of inhibition zone (mm) }\end{array}$} \\
\hline $\begin{array}{c}\text { Koncentracija pendimetalina (\%)/ } \\
\text { Concentration of pendimethalin (\%) }\end{array}$ & $\mathbf{5}$ DNN & $\mathbf{7}$ DNN & $\mathbf{1 0} \mathbf{D N N}$ & $\mathbf{1 2} \mathbf{~ D N N}$ \\
\hline 0 & $0^{\mathrm{a}}$ & $0^{\mathrm{a}}$ & $0^{\mathrm{a}}$ & $0^{\mathrm{a}}$ \\
0,165 & $0,18^{\mathrm{a}}$ & $0,35^{\mathrm{ab}}$ & $0,50^{\mathrm{ab}}$ & $0,61^{\mathrm{ab}}$ \\
0,33 & $0,22^{\mathrm{a}}$ & $0,24^{\mathrm{ab}}$ & $0,84^{\mathrm{b}}$ & $0,91^{\mathrm{b}}$ \\
0,66 & $0,47^{\mathrm{ab}}$ & $0,57^{\mathrm{b}}$ & $0,80^{\mathrm{b}}$ & $0,98^{\mathrm{b}}$ \\
1,32 & $0,94^{\mathrm{b}}$ & $1,20^{\mathrm{c}}$ & $1,75^{\mathrm{c}}$ & $2,04^{\mathrm{c}}$ \\
2,64 & $0,97^{\mathrm{b}}$ & $1,35^{\mathrm{c}}$ & $2,10^{\mathrm{c}}$ & $2,46^{\mathrm{c}}$ \\
\hline
\end{tabular}

${ }^{\mathrm{a}-\mathrm{c}}$ Vrijednosti unutar istog stupca označene istim slovima međusobno se statistički značajno ne razlikuju na razini $\mathrm{P}=0,05$

${ }^{\mathrm{a}-\mathrm{c}}$ Means followed by the same letter within a column are not significantly different according to Fisher's protected LSD at $\mathrm{P}=0.05$

$\mathrm{LSD}_{5 \mathrm{DNN}}=0,63 ; \mathrm{LSD}_{7 \mathrm{DNN}}=0,52 ; \mathrm{LSD}_{10 \mathrm{DNN}}=0,75 ; \mathrm{LSD}_{12 \mathrm{DNN}}=0,66$ 
Filipa Burul i sur.: Primjena digitalnog mikroskopa u utvrđivanju stupnja i dinamike učinka herbicida pendimetalina na rast bakterija Bradyrhizobium japonicum

Prema prikazanim rezultatima najmanji inhibitorni učinak pendimetalina na bakteriju B. japonicum, kod svih istraživanih koncentracija, utvrđen je kod prvog mjerenja (5 DNN). Prosječna širina inhibicijske zone kretala se od $0,18 \mathrm{~mm}$ kod najniže $(0,165 \%)$ do $0,97 \mathrm{~mm}$ kod najviše $(2,64 \%)$ istraživane koncentracije pendimetalina (slika 1). Između kontrolne varijante, 0,165, 0,33 i 0,66\%-tne koncentracije razlike $u$ vrijednosti širine zone inhibicije nisu bile statistički značajne dok su više istraživane koncentracije (1,32 i 2,64\%) statistički značajno inhibirale rast bakterije već kod prvog mjerenja.
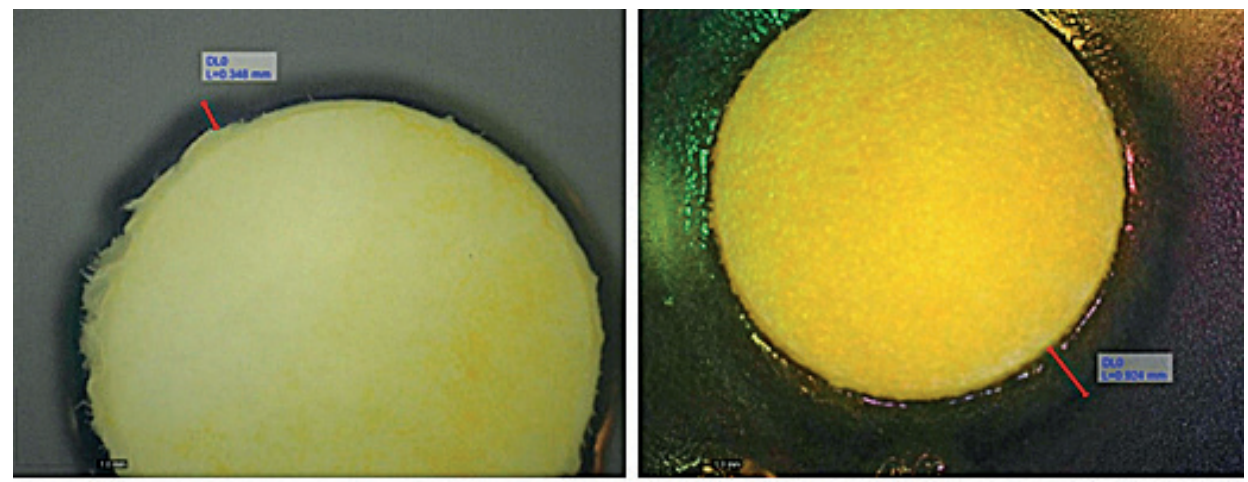

Slika 1. Širina zone inhibicije (označeno crvenim linijama) 5 DNN kod 0,165\%-tne (lijevo) i 2,64\%-tne (desno) koncentracije pendimetalina (foto: Burul, F.)

Figure 1 The width of inhibition zone (marked with red lines) 5 DAI at $0.165 \%$ (left) and $2.64 \%$ (right) concentration of pendimethalin (photo: Burul, F.)

Kod mjerenja 7 DNN kod svih istraživanih koncentracija utvrđen je porast širine zone inhibicije, što je dovelo do značajne redukcije rasta bakterijskih kolonija (slika 2). Širina zone inhibicije, u odnosu na prethodno mjerenje, znatno se razlikovala već kod najniže istraživane koncentracije $(0,165 \%)$ pendimetalina. Najmanji porast $(2 \%)$ širine zone inhibicije utvrđen je kod koncentracije od 0,33\%, dok je kod koncentracije 2,64 \% utvrđen najveći porast $(38 \%)$ u širini zone inhibicije. 
Filipa Burul i sur.: Primjena digitalnog mikroskopa u utvrđivanju stupnja i dinamike učinka herbicida pendimetalina na rast bakterija Bradyrhizobium japonicum
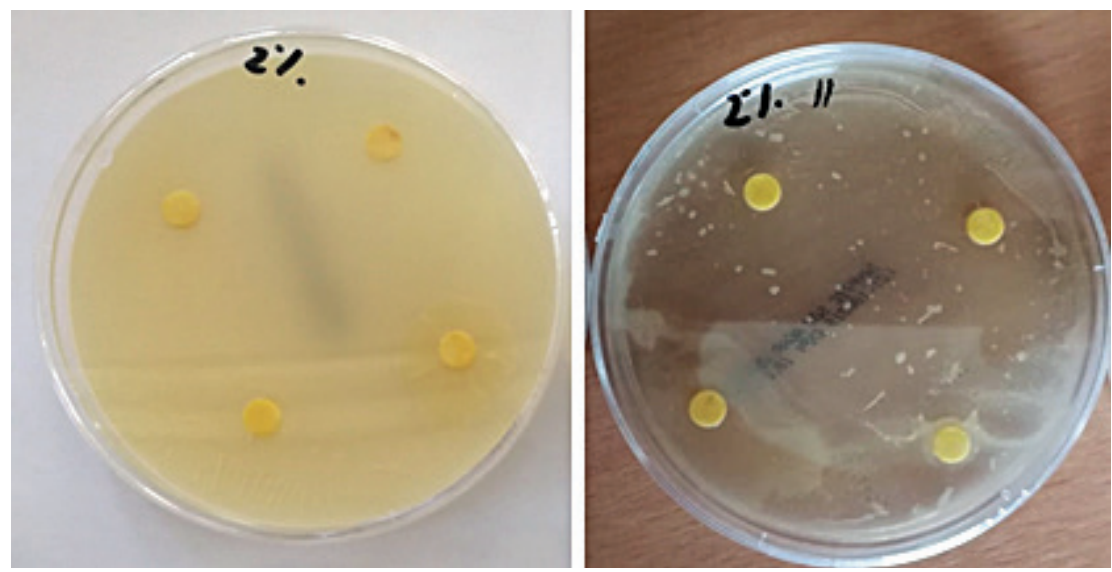

Slika 2. Rast kolonija bakterije B. japonicum kod koncentracije pendimetalina od 0,66\% 5 DNN (lijevo) i 7 DNN (desno) (foto: Burul, F.)

Figure 2 The growth of B. japonicum colony at $0.66 \%$ concentration of pendimethalin 5 DAI (left) and 7 DAI (right) (photo: Burul, F.)

Na slici 2. može se uočiti utjecaj pendimetalina na čitavu koloniju bakterije (desno vidljivije oznake na komercijalnoj podlozi). Zbog činjenice da herbicid nije bio inkorporiran u hranjivu podlogu, pretpostavlja se da je pendimetalin inkorporiran u filter-disk iskazao svojstvo hlapivosti i time djelovao plinovitim dijelom (parama) na čitavu koloniju bakterije na hranjivoj podlozi u petrijevki (Lewis i sur., 2016.).

Kod mjerenja 10 DNN značajne razlike u širini zone inhibicije, u odnosu na kontrolu, utvrđene su već kod 0,33\%-tne koncentracije pendimetalina. Kao i kod prethodnih mjerenja, tijekom vremena i porastom koncentracije povećavala se širina zone inhibicije i značajno reducirao rast bakterijskih kolonija. Najmanja širina $(0,50 \mathrm{~mm})$ zone inhibicije utvrđena je kod koncentracije od $0,165 \%$, a najveća širina $(2,10 \mathrm{~mm})$ kod koncentracije od 2,64\% (slika 3 ). 
Filipa Burul i sur.: Primjena digitalnog mikroskopa u utvrđivanju stupnja i dinamike učinka herbicida pendimetalina na rast bakterija Bradyrhizobium japonicum
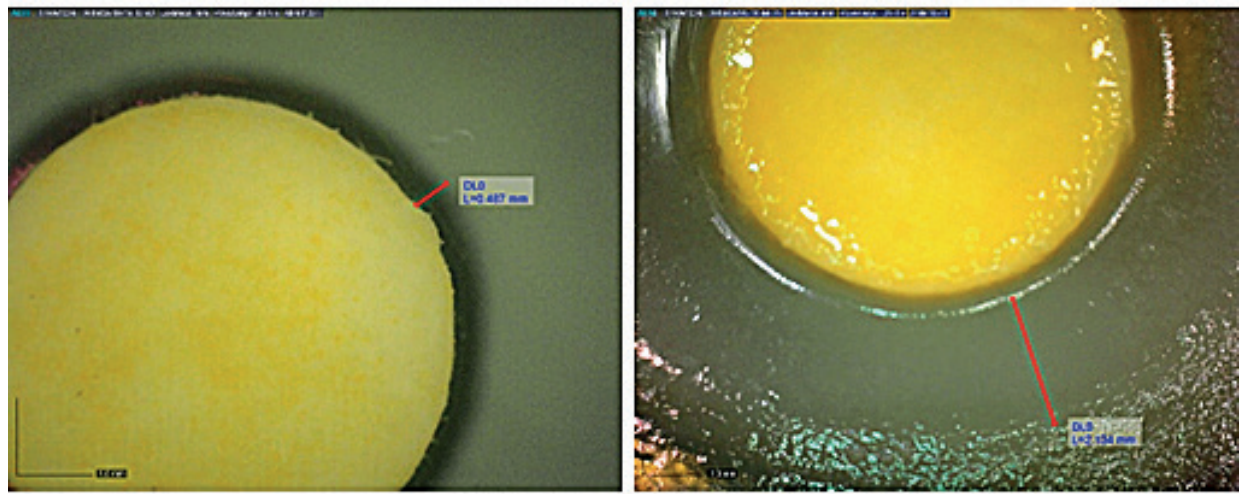

Slika 3. Širina zone inhibicije 10 DNN kod koncentracije pendimetalina 0,165\% (lijevo) i 2,64\% (desno) (foto: Burul, F.)

Figure 3 The width of inhibition zone at $0.165 \%$ (left) and $2.64 \%$ (right) concentration of pendimethalin 10 DAI (photo: Burul, F.)

Značajna progresija inhibitornog učinka pendimetalina utvrđena i kod mjerenja 12 DNN (slika 4). Porast širine zone inhibicije kretao se od 11\% kod $0,33 \%$-tne koncentracije pendimetalina do $36 \%$ kod koncentracije pendimetalina od $2,64 \%$.
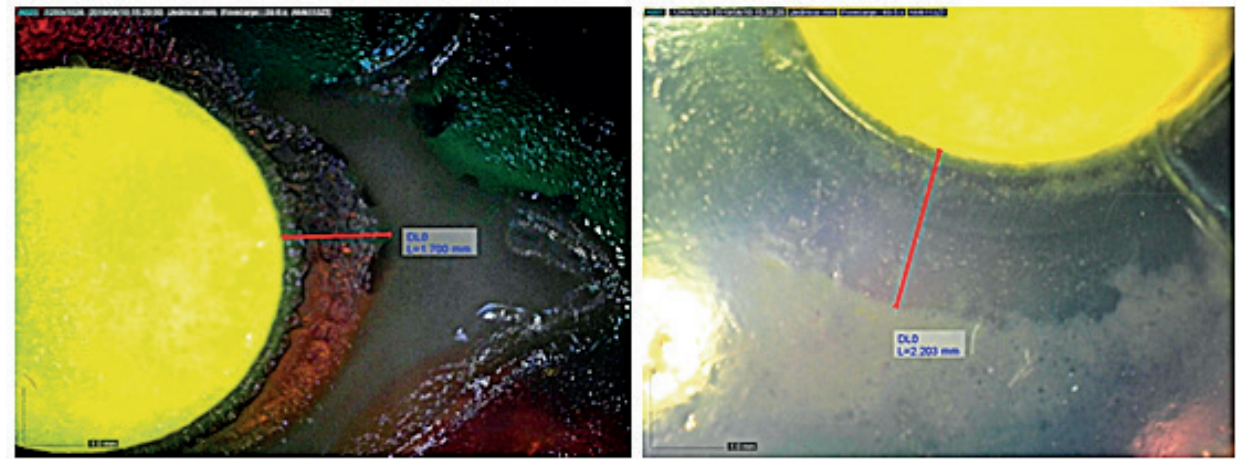

Slika 4. Širina zone inhibicije (označeno crvenim linijama) kod 1,32\%-tne koncentracije pendimetalina $10 \mathrm{DNN}$ (lijevo) i $12 \mathrm{DNN}$ (desno) (foto: Burul, F.)

Figure 4 The width of inhibition zone (marked with red lines) at 1.32\% concentration of pendimethalin 10 DAI (left) and 12 DAI (right) (photo: Burul, F.) 
Filipa Burul i sur.: Primjena digitalnog mikroskopa u utvrđivanju stupnja i dinamike učinka herbicida pendimetalina na rast bakterija Bradyrhizobium japonicum

Rezultati istraživanja razlikuju se od rezultata Bollicha (1985.) koji je pri 10 puta većim količinama pendimetalina u odnosu na količine korištene u ovom istraživanju utvrdio indiferentan učinak na bakteriju B. japonicum. Navedena neslaganja $u$ dobivenim rezultatima mogu biti zbog korištenja različitih metoda utvrđivanja učinka. U spomenutom istraživanju korištena je vizualna ocjena kao metoda utvrđivanja učinka koja, osim što se zasniva na subjektivnosti ocjenjivača, nije dovoljno precizna. Naime, upotrebom digitalnog mikroskopa, moguće je uočiti i zone inhibicije koje nisu vidljive golim oko $(<1 \mathrm{~mm})$. Rezultati istraživanja suprotni su i od rezultata Naimarevića (2014.), koji je primjenom metode inkorporacije herbicida u hranjivu podlogu utvrdio da količina pendimetalina, tisuću puta veća od propisane, stimulativno djeluje na bakteriju $B$. japonicum. Pretpostavlja se da su različiti uvjeti rasta bakterije, ovisno o primijenjenoj metodi, razlog različito dobivenih rezultata. Naime, kod filter-disk metode prisutne su zone difuzije unutar kojih je koncentracija istraživanog herbicida najveća, dok je metodom inkorporacije koncentracija herbicida jednoliko raspoređena po čitavoj površini hranjive podloge. Osim toga, soj bakterije $B$. japonicum korišten u spomenutim istraživanjima razlikovao se u odnosu na soj korišten u ovom istraživanju, što potvrđuje da unutar iste vrste bakterije, različiti sojevi mogu iskazivati različitu osjetljivost na pojedine herbicide (Malik i Tesfai, 1983.). Navedeno upućuje da se istraživanja u ovom području moraju zasebno provoditi s obzirom na vrstu i soj pojedine vrste bakterije u specifičnim pedoklimatskim uvjetima uzgoja biljke domaćina.

Rezultati istraživanja razlikuju se od rezultata Bollicha (1985.) koji je pri 10 puta većim količinama pendimetalina u odnosu na količine korištene u ovom istraživanju utvrdio indiferentan učinak na bakteriju B. japonicum. Navedena neslaganja u dobivenim rezultatima mogu biti zbog korištenja različitih metoda utvrđivanja učinka. U spomenutom istraživanju korištena je vizualna ocjena kao metoda utvrđivanja učinka koja, osim što se zasniva na subjektivnosti ocjenjivača, nije dovoljno precizna. Naime, upotrebom digitalnog mikroskopa, moguće je uočiti i zone inhibicije koje nisu vidljive golim oko $(<1 \mathrm{~mm})$. Rezultati istraživanja suprotni su i od rezultata Naimarevića (2014.), koji je primjenom metode inkorporacije herbicida u hranjivu podlogu utvrdio da količina pendimetalina, tisuću puta veća od propisane, stimulativno djeluje na bakteriju B. japonicum. Pretpostavlja se da su različiti uvjeti rasta bakterije, ovisno o primijenjenoj metodi, razlog različito dobivenih rezultata. Naime, kod filter-disk metode prisutne su zone difuzije unutar kojih je koncentracija 
Filipa Burul i sur.: Primjena digitalnog mikroskopa u utvrđivanju stupnja i dinamike učinka herbicida pendimetalina na rast bakterija Bradyrhizobium japonicum

istraživanog herbicida najveća, dok je metodom inkorporacije koncentracija herbicida jednoliko raspoređena po čitavoj površini hranjive podloge. Osim toga, soj bakterije $B$. japonicum korišten $\mathrm{u}$ spomenutim istraživanjima razlikovao se $u$ odnosu na soj korišten u ovom istraživanju, što potvrđuje da unutar iste vrste bakterije, različiti sojevi mogu iskazivati različitu osjetljivost na pojedine herbicide (Malik i Tesfai, 1983.). Navedeno upućuje da se istraživanja u ovom području moraju zasebno provoditi s obzirom na vrstu i soj pojedine vrste bakterije u specifičnim pedoklimatskim uvjetima uzgoja biljke domaćina.

\section{ZAKLJUČAK}

Na osnovi provedenog istraživanja mogu se donijeti sljedeći zaključci:

- Herbicid pendimetalin u laboratorijskim uvjetima inhibitorno djeluje na rast bakterije $B$. japonicum .

- Intenzitet inhibicije ovisio je o istraživanoj koncentraciji pendimetalina. Niže istraživane koncentracije $(0,165 ; 0,33$ i $0,66 \%)$ u početku rasta (5 DNN) bakterije nisu se statistički značajno razlikovale u odnosu na rast kolonije bakterije na kontrolnom tretmanu. Više istraživane koncentracije $(1,32$ i $2,64 \%)$ statistički značajno više su inhibirale rast bakterije B. japonicum.

- Inhibitorni učinak pendimetalina kod svih istraživanih koncentracija imao je progresivni karakter. Povećanje prosječne širine zone inhibicije u odnosu na širinu kod prvog ocjenjivanja (5 DNN) kretalo se kod zadnjeg ocjenjivanja (12 DNN) od 2,1 puta (kod 0,66\%-tne koncentracije) do 4,1 puta $(0,33 \%$-tne koncentracije).

- Subjektivnom vizualnom ocjenom utvrđeno je da pendimetalin (zbog svojstva hlapivosti), osim na područje u blizini filtar-diska, parama negativno utječe na čitavu koloniju bakterije na hranjivoj podlozi.

- Budući da je pendimetalin perzistentan i hlapiv herbicid, utvrđene inhibicije rasta bakterije $B$. japonicum u laboratorijskim uvjetima treba istražiti prikladnim metodama u poljskim uvjetima. 
Filipa Burul i sur.: Primjena digitalnog mikroskopa u utvrđivanju stupnja i dinamike učinka herbicida pendimetalina na rast bakterija Bradyrhizobium japonicum

\section{LITERATURA}

1. Blažinkov, M., Sudarević, I., Barić, K., Sikora, S., Čolo, J., Redžepović, S. (2010.): Utjecaj različitih herbicida na rast autohtonih referentnih sojeva Sinorhizobium meliloti. XXI Naučno-stručna konferencija poljoprivrede i prehrambene industrije, Zbornik radova, 1: 123-129

2. Blažinkov, M., Šnajdar, A., Barić, K., Sikora, S., Rajnović, I., Redžepović, S. (2014.): Utjecaj herbicida na rast sojeva kvržičnih bakterija koje noduliraju grašak (Pisum sativum L.). Agronomski glasnik, 76(4-5): 183-192

3. Bollich, P. K. (1985.): The Influence of Pendimethalin and Trifluralin Herbicides on the Soybean-Bradyrhizobium Japonicum Symbiosis (Nitrogen Fixation, Dinitroaniline, Glycine Max, Nodulation). LSU Historical Dissertations and Theses.

https://digitalcommons.lsu.edu/gradschool_disstheses/4117

4. Bollich, P. K., Dunigan, E. P., Jadi, A. W. M. (1985.): Effects of seven herbicides on $\mathrm{N}_{2}\left(\mathrm{C}_{2} \mathrm{H}_{2}\right)$ fixation by soybeans. Weed Science, 33: 427-430

5. Drevon, J. J. (1983.): Various organisms that fix nitrogen. U: Technical Handbook on Symbiotic Nitrogen Fixation, Legume/Rhizobium. FAO, United Nations. Biology, 2: 1-4

6. Gonzales, N., Eyherabide, J. J., Barcelonna, M. I., Gaspari, A., Sanmartino, S. (1999.): Effect of soil interacting herbicides on soybean nodulation in Balcarce, Argentina. Pesquisa Agropecuária Brasileira, 34(7): 1167-1173

7. Heatley, N. G. (1944.): A method for the assay of penicillin. Biochemical Journal, 38: 61-65

8. Johnsen, K., Jacobsen, C. S., Torsvik, V., Sørensen, J. (2001.): Pesticide effects on bacterial diversity in agricultural soils-a review. Biology and Fertility of Soils, 33(6): 443-453

9. Lewis, K. A., Tzilivakis, J., Warner, D., Green, A. (2016.): An international database for pesticide risk assessments and management. Human and Ecological Risk Assessment: An International Journal, 22(4): 1050-1064

10. Malik, M. A., Tesfai, K. (1983.): Compatibility of Rhizobium japonicum with commercial pesticides in vitro. Bulletin of environmental contamination and toxicology, 31(4): 432-437

11. Naimarević, I. (2014.): Utjecaj zemljišnih herbicida na rast sojeva Bradyrhizobium japonicum. Diplomski rad. Sveučilište u Zagrebu Agronomski fakultet 
Filipa Burul i sur.: Primjena digitalnog mikroskopa u utvrđivanju stupnja i dinamike učinka herbicida pendimetalina na rast bakterija Bradyrhizobium japonicum

12. Ostojić, Z. (1989.): Herbicidi i tlo. U: Studija o jedinstvenim kriterijima zagađivača voda, vazduha i tla na području SAP Vojvodine i potrebne hitne mere zaštite na mestima sa najvažnijim zagađivačima, 319-332

13. Redžepović, S., Sikora, S., Čolo, J., Blažinkov, M., Pecina, M. (2007.): Influence of plant growth regulator and rhizobial inoculation on nodulation and soybean nitrogen contant. Cereal Research Communications, 35(2): 993-996

14. Rosolem, C. A., Nakagawa, J., Marcondes, D. A. S. (1985.): Effects of trifluralin on nodulation and nitrogen uptake by soybean. Pesquisa Agropecuária Brasileira, 20(11): 1265-127

15. SAS Institute (1997.): SAS/STAT Soft ware: Changes and Enhancements through Release 6.12. SAS Institute Inc., Cary, NC, USA

16. Sikora, S., Blažinkov, M., Babić, K., Sudarić, A., Redžepović, S. (2008.): Symbiotic nitrogen fixation and sustainable soybean production. Cereal Research Communications, 36, 1483-1486

17. Topol, J., Kanižai Šarić, G. (2013.): Simbiotska fiksacija dušika u ekološkoj poljoprivrednoj proizvodnji. Agronomski glasnik, 5(2-3): 117-134.

18. Zahran, H. H. (1999.): Rhizobium-Legume Symbiosis and Nitrogen Fixation under Severe Conditions and in an Arid Climate. Microbiology and molecular biology reviews, 63: 968-989

\section{Adresa autora - Autor's address:}

Filipa Burul, univ. bacc. ing. agr.

Ana Pintar, mag. ing. agr.; e-mail: apintar@agr.hr

izv. prof. dr. sc. Klara Barić

Agronomski fakultet Sveučilišta u Zagrebu, Svetošimunska 25, 10000 Zagreb, Hrvatska
Primljeno - Received:

30.09.2019. 
Filipa Burul i sur.: Primjena digitalnog mikroskopa u utvrđivanju stupnja i dinamike učinka herbicida pendimetalina na rast bakterija Bradyrhizobium japonicum 